\title{
Social Entrepreneurship in Digital Age for Both Quality Pace for Economic Development
}

\author{
Lavanya V., S. Chitra
}

\begin{abstract}
In the globalized economy, entrepreneurship is the asset for economic development. Social Entrepreneurship works to bring positive social, economic environmental outcomes for the society. Social entrepreneurs, in the globalised economy thriving to fit into effective and efficient business through solving community based problems. A social entrepreneur has greater impact in achieving sustainable business models and approaches through addressing social and environmental problems. The fast paced growth of new digital technologies provides powerful resources for facing existing social and environmental challenges. The research paper aims to reveal the role of Social entrepreneur benefits and Challenges in developing our Economy. The research is of an empirical nature and primary data are collected using convenient sampling techniques through a structured questionnaire. The study outcome will help the social entrepreneurs to enhance their business worth and for economic development.
\end{abstract}

Keywords: Social Entrepreneurs, Digital, Challenges, Opportunities, Economic Development.

\section{INTRODUCTION}

"Social entrepreneurs are not content just to give a fish or teach how to fish, They will not rest until they revolutionized the fishing industry"1- BILL DRAYTON

In the globalised economy social entrepreneurs cultivates a community of change maker they seeks the world now requires everyone to be a change leaders. Social entrepreneurs are the individuals with innovative solution to society most prevailing in social, cultural and environmental challenges. In India social entrepreneurs works to promote inclusive growth, development and to contribute change in the society through entrepreneurial vision of the economy.

Social entrepreneurs in the business world act as a growth steam, opportunity seeker and innovation maker to economic advancement on the other side they act as a individual who recognize a prevailing social, cultural, environmental challenges and give solutions using

Entrepreneurial traits in changing the system of society. They became invaluable resource to the economy to enter the mainstream profession for the overall welfare of the nation. The fast paced growth of digitalization helped social

Revised Manuscript Received on December 05, 2019.

* Correspondence Author

Lavanya V.*, Assistant Professor and Part-Time Interrnal scholar, Department of Commerce, Faculty of Science and Humanities, SRM University - Institute of Science and Technology, Kattangalathur Campus, Chennai, India. E-mail: lavanya.vk@ktr.srmuniv.ac.in

Dr. S. Chitra, Research Supervisor \& Associate Professor, Department of Commerce, Faculty of Science and Humanities, SRM University - Institute of Science and Technology, Kattangalathur Campus, Chennai, India. E-mail: hod.com@ktr.srmuniv.ac.in entrepreneurs to innovate increasingly and have become cost effective to deploy technology to solve social problems. Indeed they proved in many countries in helping people at large scale. However, at the same time there are many challenges faced by them. This research paper intends to study social entrepreneurs pace in overall development of the Nation. Hence these challenges need to be addressed to enhance their business worth and also for the growth of society.

Notable Modern Social Entrepreneurs In India

\begin{tabular}{|c|c|c|}
\hline NAME & $\begin{array}{c}\text { SOCIALVENTURE } \\
\text { FOUNDED }\end{array}$ & FOCUS AREA \\
\hline Zubaida Bai & AYZH & Health care \\
\hline Ela Bhatt & $\begin{array}{c}\text { Self employed } \\
\text { women association }\end{array}$ & Poverty \\
\hline $\begin{array}{c}\text { Nand Kishore } \\
\text { Chaudhary }\end{array}$ & Jaipur rugs & Poverty \\
\hline $\begin{array}{c}\text { Abraham } \\
\text { George }\end{array}$ & $\begin{array}{c}\text { The George } \\
\text { Foundation }\end{array}$ & Poverty \\
\hline $\begin{array}{c}\text { Anshu Gupta } \\
\text { Goonj }\end{array}$ & $\begin{array}{c}\text { Clothing, Disaster } \\
\text { relief }\end{array}$ \\
\hline Bunker Roy & Barefoot college & Education \\
\hline
\end{tabular}

Source: Wikipedia

\section{REVIEW OF LITERATURE}

Tanvi Gandhi and Rishav Raina (2018)2 on their studyin social entrepreneurialism: a need, significance, aspects and restraints on social entrepreneurship were progressively become a key component throughout the worldwide conversation of charitable help and community engagement. Social entrepreneurs highlight methods of mitigating or eliminating societal pressures and creating radical externalities or government property. This research focuses mainly on both the significance of social entrepreneurship to different mediums or where it represents in today's world in regards to several other types of entrepreneurship.

Sergey Mikhailovochi V Asin Russia (2017)3 on the challenges of social innovation: approaches and key mechanism of development analyzed the key mechanism of social innovation were identified, including that of innovation mediation. The system capabilities of living labs in the promotion of social innovators were in particularly investigated. 
Doherty et al., (2014)4 realized that perhaps the parameters around semi-profit accomplishments and revenue-making objectives was declining and being more dynamic with the current developments. They examined the above component extensively. To replicate diversity of nonprofit organization, they were using extensive scanning to pick available research literature and presented a methodology analysis. This assessment aided them to design the importance of the concept to the procedures of handling social businesses. The research emphasized multiple concerns about both the implementation of management procedures of socialenterprises.

Sarah H. Alvord, L.David Brown, Christine W. Letts Harvard University (2004)5 on both the review on social entrepreneurship and social transformation-An exploratory research assessed factors leading to substantial political, economic and social circumstances for poor and marginalized communities. They draw the conclusion with a consideration on the consequences of practical terms, analysis, and advancement for social entrepreneurship

\section{OBJECTIVES OF THE STUDY}

1. To identify role of social entrepreneurship in digital age for developing oureconomy

2. To understand the challenges and benefits of social entrepreneurs to improve performance.

\section{RESEARCH METHODOLOGY}

Research is an academic activity that involves identifying the research problems, formulating a hypothesis, collecting and analyzing the data to reach the conclusion in the form of solution or general theories.

\section{A. Sample Technique}

The method of sampling used was convenient sampling. The sample size considered of 50 entrepreneurs in Chennai city. The following are the sources of data used by the researcher Primary data and Secondary data: The primary data will be collected as a mode of data collection using digital survey and telephone survey. Separate sets of structured questionnaires prepared for social entrepreneurs to conduct surveys. Additional secondary information is gathered from numerous books, newspapers, periodicals as well as business websites

\section{STUDY LIMITATION}

1. The study mainly focuses on Chennai City only. Therefore it is impossible to identify the findings as a representative of the whole nation.

2. Entrepreneurs include small sized entrepreneurs only.

3. The time period given is also a major concern to collect the data within the short span of time the research work isdone.

\section{DATA ANALYSIS AND INTREPRETATION}

For the purpose of the study convenience statistics were used for computing using SPSS in analyzing the data obtained from samples and the analysis is computed. The statistical tools used for analysis is Factor analysis and Chi square test and ANOVA.

Table 1: Factor Analysis - KMO and Bartlett's Test - Total Variance Explained - Rotated Component Matrix Loadings

\begin{tabular}{|c|c|c|c|c|c|c|}
\hline \multicolumn{6}{|c|}{ Kaiser-Meyer-Olkin Measure of Sampling Adequacy. } & .883 \\
\hline \multirow{3}{*}{\multicolumn{3}{|c|}{ Bartlett's Test of Sphericity }} & \multicolumn{3}{|c|}{ Approx. Chi-Square } & 1022.321 \\
\hline & & & \multicolumn{3}{|c|}{ Df } & 68 \\
\hline & & & \multicolumn{3}{|c|}{ Sig. } & .000 \\
\hline \multicolumn{7}{|c|}{ Total variance explained } \\
\hline \multirow{2}{*}{ Component } & \multicolumn{3}{|c|}{ Initial Eigen values } & \multicolumn{3}{|c|}{ Rotation sums of squared Loadings } \\
\hline & total & $\%$ of variance & Cumulative $\%$ & total & $\%$ of variance & Cumulative\% \\
\hline 1 & 6.151 & 51.258 & 51.258 & 4.653 & 38.778 & 38.778 \\
\hline 2 & 1.432 & 11.936 & 63.194 & 2.930 & 24.416 & 63.194 \\
\hline \multicolumn{7}{|c|}{ Extraction method: principal component analysis } \\
\hline
\end{tabular}




\begin{tabular}{|l|c|c|}
\hline \multicolumn{1}{|c|}{ Rotated component matrix } & Loadings & Communalities \\
\hline Digital Factor & & \\
\hline Social enterprise finds expensive in developing digital innovativeness & .918 & .617 \\
\hline Difficulty in Securing funding ICT & .876 & .712 \\
\hline Lack of IT knowledge & .779 & .878 \\
\hline Difficulty in hiring technology specialist & .773 & .818 \\
\hline Social entrepreneurs use digital technology but the cant create them & .736 & .529 \\
\hline Lack of Acquiring technologies & .554 & .673 \\
\hline Govt. Support Factor & & .456 \\
\hline Identifying capital investment is challenging & .811 & .892 \\
\hline Difficult in finding right business center & .801 & .632 \\
\hline Mission Drift & .723 & .746 \\
\hline Low profit Margin & .665 & .635 \\
\hline Charismatic leader failed to recognize & .523 & .415 \\
\hline Difficulty in undertaking Govt projects & .498 & \\
\hline
\end{tabular}

In order to determine the problems of social Entrepreneurs, An exploratory factor analysis has been carried out on twelve parameters included in the survey from Table 1. In the above tables, the main component analysis with varimax is presented the study encompasses only Kaiser-Meyer-Olkin Barlett evaluation tables, Total Variance values described, Component Matrix value and Rotated Component Matrix value, Communities tables. The statistical analysis in this table is shown below.

Kaiser-Meyer-Olkin statistics show relatively compact correlations. Barlett test also means that the variables have a relationship. Kaiser-Meyer-Olkin sampling adequacy measure is 0.883 , which at 5 percent is statistically significant. It can therefore be concluded that the sample size is sufficient for the factors to be derived.

The variables community ranges from.415 to.878 indicating large quantities of variance as extracted by factor solution. For the problems faced by social Entrepreneurs, the main component analysis is performed to verify whether the variables can be reduced to a few significant variables.

All 2 extracted factors that are those with an own value of more than 1 account for the variance in the matrix of the item variance-covariance. It can be noted that with the percentage value of $38.778,63.194$ the variables are reduced to predominant factors. From the rotated matrix table created as the first factor that can be appropriately named with grouping as "digital factors" with grouping six variables. The second factor with grouping of six variables called "Govt support factors". This reveals that two predominant factors result in factor analysis. In other words, based on the inter-relationship between themselves, 12variables are grouped into two factors. It can therefore be concluded that digital factors and Govt support factors are the two major factors that pose a major challenge to social Entrepreneurs from the outside force and government internal support.
Hence it can be concluded that Digital factors Govt Support factors are the

two major factors being challenging to social entrepreneurs in developing economy.

Table 2: Showing the one way Anova between experience in digital and benefits associated to social entrepreneurs in empowering digital economy.

HO - There is no significant difference between experience in social enterprise and benefits associated to social entrepreneurs in developing economy.

ANOVA test as been executed to test the hypothesis.

\begin{tabular}{|l|c|c|}
\hline $\begin{array}{c}\text { Benefits of digital entrepreneurs for rural } \\
\text { development }\end{array}$ & $\begin{array}{c}\mathbf{F} \\
\text { value }\end{array}$ & $\begin{array}{c}\mathbf{P} \\
\text { value }\end{array}$ \\
\hline Help communities to improve quality of life & 3.498 & .006 \\
\hline Creating inspiring and innovative solutions & 3.997 & .027 \\
\hline Improve their ability to achieve their aim & 6.845 & .020 \\
\hline $\begin{array}{l}\text { Relying on Continuous innovation and } \\
\text { creativity }\end{array}$ & 9.125 & .001 \\
\hline Improve standard of living & 13.675 & .000 \\
\hline Strive to tackle social problems & 15.322 & .005 \\
\hline Creating mission to social impact & 17.034 & .021 \\
\hline Creating more Job opportunities & 20.990 & .000 \\
\hline Improving Education & 22.435 & .012 \\
\hline
\end{tabular}


Empowering to create change

$22.121 \quad .000$

It is inferred from the table above that the p-values are less than the level of the table value (0.05).

Therefore, it rejects null hypothesis and accepts alternative hypothesis. Now it can be concluded that between experience in digital and benefits are associated to social entrepreneurs.

Table 3: Showing association between experience of the social entrepreneurs and major problem is mission drift.

Ho - There is no significant association between experience of the social entrepreneurs and major problem is mission drift. Chi square test as been executed to test the hypothesis.

\section{Chi-Square Tests}

\begin{tabular}{|c|c|c|c|}
\hline & Value & df & $\begin{array}{c}\text { Asymp. Sig. } \\
(2- \\
\text { sided })\end{array}$ \\
\hline Pearson Chi-Square & $21.940 \mathrm{a}$ & 15 & .115 \\
\hline Likelihood Ratio & 24.773 & 16 & .047 \\
\hline $\begin{array}{c}\text { Linear-by-Linear } \\
\text { Association }\end{array}$ & 1.850 & 1 & .174 \\
\hline Number of Valid Cases & 50 & & \\
\hline
\end{tabular}

Source: Computed Data

It is inferred from the table above that the p-values .115 is higher than the level of the table value (0.05). Therefore, it rejects alternative hypothesis and accepts null hypothesis. Now it can be concluded there is no significant association between experience of the social entrepreneurs and major problem is mission drift is accepted.

\section{FINDINGS}

In this study the researcher has examined some variables that are being challenges and some variables that influence the social entrepreneurs to take advantage and to get benefited from them. So it can be concluded that social entrepreneurs are facing challenging in making up of innovativeness, Social enterprise finds expensive in developing digital innovativeness, Difficulty in Securing funding ICT, Lack of IT knowledge, Difficulty in hiring technology specialist, Social entrepreneurs use digital technology but the cant create them, Lack of Acquiring technologies, Identifying capital investment is challenging, Difficult in finding right business center, Mission Drift, Low profit Margin, Charismatic leader failed to recognize, Difficulty in undertaking Govt projects are the major challenges for social entrepreneurs. There is a significant difference between experience in social enterprise and benefits are associated to entrepreneurs in making up of our economy.

\section{SUGGESTION AND CONCLUSION}

Social entrepreneurship has become a strategy for developing an innovative, sustainable and large scale solution to business. The revolution of computers and mobile phones has changed the entrepreneurs as change maker in the business world. Technology provides the ability to combine the efforts, knowledge and ideas to reach the end goal. Social entrepreneur should utilize the maximum resource available. To achieve with this social entrepreneurs should start off with a small scale experiment, exploit want is known, leverage strong connections, build a lean but multitalented team. Social businesses are working to develop and implementing advancement, providing economic and social growth prominence and introducing new goods and services. They deal with issues connected with some of the massive societal concerns, such as lack of intelligence, impoverishment, as well as lack of vital medical services. Hence the Government of India should give guidance on raising the profile of entrepreneurs as a vehicle for strengthen communities, encourage and corporate to put money in providing vital support, introducing new finance models, to engage in match trading, bringing together local hubs for learning and connection and proper attention should be given to the support factors digital factors to get benefited by social entrepreneurs to improve the business worth, for the society and to develop the economy.

\section{REFERENCES}

1. www.forbes.com.ashoka "social entrepreneurship by Bill Drayton"

2. Tanvi Gandhi. and Rishav Raina.(2018) "Social entrepreneurship: need, relevance, facets and constraints" Journal of Global Entrepreneurship Research, vol 8:9, pp. 1-13.

3. Sergey mikhailovochi, v asin. Russia (2017) "Challenges of social innovation: approaches and key mechanism of development"European research studies journal, vol 12, issue $2 \mathrm{~b}, \mathrm{pp} .25-45$.

4. Doherty, B. Haugh, H. Lyon, F. (2014), "Social enterprises as hybrid organizations: A review and research agenda",International Journal of Management Reviews, vol.16(4), pp.417-436

5. Sarah H.alvord, L. David brown, Christine W,Letts.(2004), "social entrepreneurship and societal transformation: An exploratory study",The journal of applied behavioural science, vol 40, no3, pp. 260-282.

6. www.forbes.com.ashoka

7. List of social entrepreneurs -Wikipedia

8. Bezencon, V. and Blili, S. (2009), "Fair trade managerial practices: strategy, organisation and engagement', Journal of Business Ethics, Vol. 90 No. 1, pp. 95-113.

9. Allan, B. (2005), "Social enterprise: through the eyes of the consumer (prepared for the National Consumer Council)", Social Enterprise Journal, Vol. 1 No. 1, pp. 57-77.

10. Boluk, K.A. and Mottiar, Z. (2014), "Motivations of social entrepreneurs: blurring the social contributionandprofitsdichotomy",SocialEnterpriseJournal,Vol.10No.1,p p.53-68.

11. Germak, A.J. and Singh, K.K. (2010), "Social entrepreneurship: changing the way social workers do business", Administration in Social Work, Vol. 34 No. 1, pp. 79-95.

12. Venkataraman, S. and Shane, S. (2000), “The promise of entrepreneurship as a field of research", The Academy of Management Review, Vol. 25 No. 1, pp. 217-226

13. Wilson, F., Kickul, J. and Marlino, D. (2007), "Gender, entrepreneurial self-efficacy, and entrepreneurial career intentions: implications for entrepreneurship education", Entrepreneurship: Theory and Practice, Vol. 31 No. 617 , pp. $387-406$ 


\section{AUTHORS PROFILE}

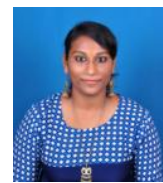

Ms. V. Lavanya, M.Com, M.Phil, $\mathrm{PhD}$ (pursuing) Assistant Professor in the Department of Commerce, Faculty of Science \&Humanities, SRM Institute of Science and Technology, Chennai. Ph.D (Pursuing) in commerce from SRM Institute of Science and Technology registered during 2018, M.Phil in Commerce from Madras Christian College during 2016-2017 and M.Com in Commerce Madras Christian College, Chennai during 2014-2016 and B.Com from Guru Nanak College,

Chennai during 2011-2014. Published more than 15 research papers in both national and international conference and presented 17 papers in conference. Working paper on Women Empowerment through Social Entrepreneurship. Acted as a Organizer for two day workshop on SPSS conducted on January, 2019, Organizer for two days International conference on Business Research, 2018 and 2019, University central examination camp - Acted as camp coordinator 2018 .

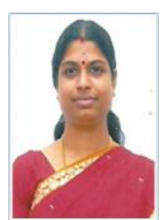

Dr. S. Chitra, M.com, M.Phil, Ph.D is an Associate professor, HOD of the Department of Commerce, Faculty of Science \& Humanities, SRM Institute of Science and Technology, Chennai. Awarded Ph.D in Management from SRM Institute of Science and Technology (formerly known as SRM University) in the year 2014, M.Phil in Commerce from Madurai Kamaraj University at 2004and M.Com Commerce from Madras University, 2002. Published more than 19 research papers in both national and international conference and presented 32 papers in conference. Research on Awareness and Eradication of Cancer in New Millennium among Youths in Chennai City, Project approved by Directorate of Research - SRM Institute of Science and Technology. Awarded as Best Faculty for the Year 2015-2016 by Cognizant Technologies also acted as an Expert person in conferences. Advisory Board Member of Tamil Perayam, Academic Council Member of SRM Institute of Science and Technology and Board of Studies Member and Coordinator for Syllabus Committee since 2012 